\title{
Genetic Polymorphisms of IGF1, GH, and OPN Genes in Crosses Peranakan Ongole Cattle Based on Birth Type in Central Java
}

\author{
Anggraeni $\mathrm{A}^{1}$, Talib $\mathrm{C}^{1}$, Asmarasari $\mathrm{SA}^{1}$, Herawati $\mathrm{T}^{1}$, Andreas $\mathrm{E}^{2}$ \\ ${ }^{1}$ Indonesian Research Institute for Animal Production, PO Box 221 Ciawi, Bogor, Indonesia \\ ${ }^{2}$ Faculty of Animal Science, Bogor Agriculture University, Bogor, Indonesia \\ E-mail: ria.anneke@yahoo.co.id
}

(received 13-11-2017; revised 27-11- 2017; accepted 11-12-2017)

\begin{abstract}
ABSTRAK
Anggraeni A, Talib C, Asmarasari SA, Herawati T, Andreas E. 2017. Polimerfisme genetik dari gen IGF1, GH dan OPN pada persilangan sapi PO berdasarkan tipe kelahiran di Jawa Tengah. JITV 22(4): 165-172. DOI: http://dx.doi.org/10.14334/jitv.v22i4.1625

Polimorfisme genetik dari gen IGF1, GH, dan OPN pada sapi hasil persilangan Sapi Peranakan Ongole (PO) silangan Berdasarkan Tipe Kelahiran di Jawa Tengah. Perbaikan produktivitas dengan cara menyilangkan sapi PO terhadap sapi potong eksotik melalui kawin IB disukai banyak peternak di Jawa Tengah. Fertilitas menentukan kemampuan seekor induk sapi dalam menghasilkan anak. Gen IGF1 diduga mempengaruhi kelahiran kembar dan ganda pada sapi, sedangkan gen GH dan OPN menentukan kesuburan reproduksi. Polimorfisme genetik ketiga gen ini dipelajari pada sapi PO silangan untuk kelahiran tunggal (T) dan kelahiran (histori) kembar dan ganda (G) berasal dari dua kabupaten di Jawa Tengah, yaitu dari Sragen $(T=7$ ekor, dan $G=13$ ekor) dan dari Kendal $(T=9$ ekor, dan $\mathrm{G}=16$ ekor). Polimorfisme genetik diidentifikasi dengan metoda PCR-RFLP (polymerase chain reaction - restriction fragment length polymorphism) menggunakan enzim restriksi SnaBI (gen IGF1), MSpI (gen GH), dan BsrI (gen OPN). Lokus IGF1|SnaBI dari sapi PO silangan yang diamati tidak memberikan varian SNP atau bersifat monomorfik untuk tipe kelahiran tunggal maupun kembar dan ganda. Sebaliknya lokus GH|MSpI dan OPN|BsrI bersifat polimorfik dengan tingkat keragaman cukup tinggi. Disimpulkan lokus IGF1| SnaBI tidak bisa dipakai untuk melihat kemungkinan adanya kontrol genetik kelahiran kembar (ganda), tetapi lokus GH|MSpI dan OPN|BsrI bisa dipertimbangkan sebagai informasi awal untuk seleksi molekular pada sifat kesuburan dari sapi potong.
\end{abstract}

Kata Kunci: Sapi Potong, Polimorfisme Genetik, Gen Kesuburan

\begin{abstract}
Anggraeni A, Talib C, Asmarasari SA, Herawati T, Andreas E. 2017. Genetic polymorphisms of IGF1, GH, and OPN genes in crosses Peranakan Ongole cattle based on birth type in Central Java. JITV 22(4): 165-172. DOI: http://dx.doi.org/10.14334/jitv.v22i4.1625

Genetic Polymorphisms of IGF1, GH, and OPN Genes in Crossbred of Peranakan Ongole Cattle Based on Birth Type in Central Java. Improved productivity by crossing Peranakan Ongole (PO) cattle to exotic beef cattle through AI mating is preferred by many farmers in Central Java. Fertility determines the ability of a cow to give birth. IGF1 gene is predicted to affect either twin or multiple births in cattle, whereas GH and OPN genes determine reproductive fertility. Genetic polymorphisms of these three genes were studied in the crossbred of PO cattle for single birth (S) as well as twin and multiple (M) births or their historical (M) ones from two districts in Central Java, from Sragen ( $S=7$ hd and $M=13$ hd.) and from Kendal ( $S=9$ hd, and $M=16$ hd.). Genetic polymorphisms were identified by PCR-RFLP (polymerase chain reaction - restriction fragment length polymorphism) method using restriction enzymes of SnaBI (IGF1 gene), MSpI (GH gene), and BsrI (OPN gene). IGF1|SnaBI locus in the observed crossbred PO did not have SNP polymorphism or monomorphic for single and twins or multiple births. In contrast, GH $\mid M S p I$ and OPN $\mid B s r I$ loci were polymorphic with quite a high degree of diversity. In conclusion, the IGF1|SnaBI locus cannot be used to investigate possible genetic control of twins and multiple births, whilst $\mathrm{GH} \mid M S p \mathrm{I}$ and $\mathrm{OPN} \mid B s r \mathrm{I}$ polymorphisms can be considered as initial information for selection on fertility traits in beef cattle.
\end{abstract}

Key Words: Beef Cattle, Genetic Polymorphism, Fertility Genes 


\section{INTRODUCTION}

Beef cattle have a strategic role in producing red meat for the national population. Java Island is one of the centers of national beef cattle agribusiness, with the highest beef cattle population in the year 2016, as an example, are from East Java 4.407.807 hd., Central Java 674.573 hd., West Java 413.372 hd., and Yogyakarta Special Regency 309.018 hd respectively (DGLAH 2017). Central Java thus becomes one of the national beef cattle production. Animals are mostly raised by small farmers under a cow-calf operation (CCO) system. Crossbreeding through artificial insemination technique is preferred especially by farmers in many areas in Central Java. This is due to adequate facilities and human resources (inseminator) in supporting the easy implementation for artificial insemination (AI) mating. The crossing is preferred because farmers like calves to grow rapidly to give heavier weights, compared to those calves of local beef cattle. Crosses by AI mating are usually performed between local Peranakan Ongole (PO) cattle by the frozen semen of exotic beef cattle bulls mainly from Bos taurus, such as Simmental, Limousine, and Brahman.

The ability of reproduction of a cow to produce a calf within a short calving interval (around 12 months) is crucial for the success of beef cattle agribusiness. Another aspect that is also interesting to note, is to see the chances of twinning or multiple births in beef cattle. Large ruminant is very well known as uniparous species. It is very common for beef cattle to have a single calf in one birth (Komisarek \& Dorynek 2002; Çobanoğlu 2010). However, at a low level, incidences of cows calving twins or multiple calves per birth occur. The natural frequency of twin and multiple parturitions in cattle ranges from $0.5-4 \%$ depending on many genetic and environmental factors (Sawa et al. 2012). Many studies have reported the cows of having twinning and multiple births without extra management and health services could cause detrimental for both cow and calves. Some negative effects from twin and multiple pregnancies were for decreasing fertility of cows by causing longer calving interval by $18 \mathrm{~d}$., reproductive rest period by 9 d., and service period by $10 \mathrm{~d}$., as well as increasing services per conception by 0.15 (Sawa et al. 2012). Twins and multiple births cause to lessen overall cow reproductive efficiency and productivity. However, twinning and multiple calves can give profitability under an intensive beef cattle breeding condition. Twinning or multiple births were possible to improve biological efficiency and production as a result of lower input costs during pregnancy and lactation cows (Karlsen et al. 2000).

Using molecular technology makes it possible to identify possible genes for having the control on twins and multiple births in beef cattle. Twins and multiple births in cows are known as a trait that follows a quantitative pattern, controlled by many genes. In addition, reproductive traits have many limitations for genetic improvement due to low heritability, sex-related expression, and difficult phenotypic measurements (Singh et al. 2014). The molecular selection at DNA level may help to get an earlier decision-making of animals to be considered as breeding stocks. Many studies have investigated genetic polymorphisms of major genes in relation to their effect on fertility. A number of growth and reproductive genes are predicted to affect twins and multiple births in cattle. Those genes are thought in affecting the number of ova produced and the number of transferable embryos, leading as potential gene markers for superovulation response (Yang et al. 2010; Deb et al. 2012; Singh et al. 2014).

Twinning rate in cattle is basically a sequential product of ovulation rate, conception rate, and embryo survival. Twinning and ovulation rates in cattle are strongly genetically correlated $(0.75-0.9)$ (Gregory et al. 1997). This indicates the two traits are influenced by common loci (Lien et al. 2000). Certain variant SNPs or genotypes of IGF1 gene are presumed for having genetic control on twins and multiple births in beef cattle. A study by Echternkamp et al. (1990) proved that twinning and multiple pregnancies in cattle is associated by the increasing IGF-1 concentrations in both blood serum and follicular fluid. The IGF-1 stimulates mitogenesis of granulosa cells and steroidogenesis of ovarian cell cultures. This gene plays an important role in the regulation of folliculogenesis and may be involved in the process of multiple ovulations in cattle. IGF1 gene stimulates ovarian function by acting with gonadotropins to promote growth and steroidogenesis of ovarian cells (Lucy 2001). This is essential in stimulating multiple ovulation rates to give potential twins or multiple pregnancies during the process of fertilization.

GH and OPN genes are two of the other genes that play another role in maintaining twins and multiple pregnancies in cattle. Their roles are to give success on conception rate and embryo survival. Osteopontin (OPN) gene in cattle is located at chromosome 6 (BTA6) closed to quantitative trait loci (QTL) of fertility and milk production (Leonard et al. 2005). OPN is known as secreted phosphoprotein 1 (SPP1). OPN is expressed on maternal and foetal interface suggesting indicating that OPN gene has an important role in maintaining uterine-embryonic microenvironment (Johnson et al. 2003). This gene has the function to profoundly impact pregnancy, embryo implantation and placental development ( $\mathrm{Li}$ et al. 2013). Whereas Growth Hormone (GH) gene plays a key role in postnatal growth and developments in tissue, muscle, bone, adipose tissue, udder gland (Sami et al. 2011). $\mathrm{GH}$ gene is involved in the processes of sexual 
differentiation and pubertal maturation as well as participated in gonadal steroidogenesis, gametogenesis and ovulation. This gene has additional roles in pregnancy and lactation through the actions as reflecting direct endocrine actions of pituitary $\mathrm{GH}$ or be mediated by its induction of hepatic or local IGF-I production (Hull \& Harvey 2001). Significant relationships have been reported between $\mathrm{GH}$ concentrations and postpartum period and fertility of cows (Lucy 2008).

This study was aimed to investigate genetic polymorphisms of IGF1, OPN and GH genes in the crossbred PO cattle from two districts in Central Java Province. Information on genetic polymorphisms at certain DNA fragments of IGF1, OPN, and GH genes can be useful to investigate possible genetic control of twins and multiple births as well as fertility traits in beef cattle.

\section{MATERIALS AND METHODS}

\section{Beef cattle as samples}

Animals as samples in this study were crossed Peranakan Ongole (PO) cattle as the offsprings of crossbreeding PO females to exotic beef cattle breeds such as Simmental, Limousin, and Brahman. The crossed PO cattle were observed from Sragen Regency and Kendal Regency in Central Java Province. A female or a cow determined of having twins or multiple births was that cow for giving twins or multiple births at least once during her life, while that of historical twin or multiple births was that animal calved from twins or multiple births. Abbreviation of cows having (historical) twins or multiple births called M, whilst cow with single birth was grouped as control (S). A total number of the crossed PO cattle observed from Sragen amounted by 20 hd., consisting of the cows having twins or multiple births (M) by 13 hd. (9 females and 4 males), while those with single birth (S) by 7 hd. (all females). Further, the total number of the crossed PO cattle from Kendal were 25 hd, consisting the cows having twins or multiple births (M) by 16 hd (15 females, 1 male), while cows having single birth (S) by 9 hd. (4 females, 5 males).

\section{Blood collection}

All of those crossed PO cattle as samples were collected their fresh blood. Blood samples were taken for DNA analysis collected from jugular vein using a 21 G X $1 \frac{1}{1 / 2}$ sized vacutainer or $10 \mathrm{ml}$ syringe containing heparin anticoagulant substance. A total of 1 to $2 \mathrm{ml}$ of blood samples was stored in a $10 \mathrm{ml}$ tube and added 8 $\mathrm{ml}$ of ethanol (EtOH) absolute containing $1 \mathrm{mM}$ EDTA).

\section{DNA extraction}

DNA extraction was done by following four steps. 1. Sample preparation: $200 \mu$ blood sample was inserted into $1.5 \mathrm{ml}$ tube, added by distilled water 1000 $\mu \mathrm{l}$, and centrifuged at $8000 \mathrm{rpm}$ for $5 \mathrm{~min}$. 2 . Degradation of protein: 1xSTE sample was added to a solution of $350 \mu \mathrm{l}, 40 \mu \mathrm{l}$ SDS $10 \%$ and $10 \mu \mathrm{l}$ proteinase $\mathrm{K} 5 \mathrm{mg} / \mathrm{ml}$ and incubated at $55^{\circ} \mathrm{C}$ for 2 hours. 3 . Degradation of organic matter: the solution was added to $400 \mu \mathrm{l}$ of phenol, $400 \mu \mathrm{l}$ chloroform-isoamyl alcohol (24: 1) and $40 \mu \mathrm{l} \mathrm{NaCl}$, then gently whisked at a room temperature for 1 hour. 4. DNA precipitation was performed by adding: $400 \mu \mathrm{l}$ supernatant added $40 \mu \mathrm{l}$ $\mathrm{NaCl} 5 \mathrm{M}$ and $800 \mu \mathrm{l}$ ethanol absolute, homogenized, frozen overnight.

\section{DNA amplification}

DNA genomes of the crossed PO cattle from single birth and twin (multiple) births were used as template in DNA amplification reaction (PCR reaction). The primer used for IGF1 gene, namely forward 5CCTCTGCGGGGCTGAGTTGGT-3 and reverse 5CGACTTGGCGGGCTTGAGAGGC-3 following Siadkowska et al. (2006). Primer used for Osteopontin (OPN) gene, namely forward GCAAATCAGAAGTGT GATAGAC-3, and reverse CCAAGCC AAACGTATGAGTT-3 following Leonard et al. (2005). While Growth Hormone $(\mathrm{GH})$ gene used two pairs of primers, namely forward CCC ACG GGC AAG GC and GAG AAG; and reverse TGA GGA ACT GCA GGG GCC CA in accordance to Zhou et al. (2005).

\section{PCR reaction}

PCR reaction was performed with a total volume of $25 \mu \mathrm{l}$ of solution mixture comprising Taq Polymerase DNA and 10X Taq Polymerase buffer (100 mM Tris$\mathrm{Cl}$, pH 8.3, 500mM KCL; $15 \mathrm{mM} \mathrm{MgCl}_{2} ; 0.01 \%$ gelatin); dNTP'S mix (dGTO, dATP, dTTP and dCTV) (Pharmacia); and sterile $\mathrm{dH}_{2} \mathrm{O}$. While PCR reaction conditions in the thermocycler engine were designed with pre-denaturation temperature by $93^{\circ} \mathrm{C}$, denaturation by $94^{\circ} \mathrm{C}$, annealing by $58-60^{\circ} \mathrm{C}$, extension by $72^{\circ} \mathrm{C}$, and post PCR $4^{\circ} \mathrm{C}$. Cycles were repeated 33 times for multiplication. 


\section{Genotyping}

To detect genetic variants of specific base fragments of each IGF1, OPN and GH genes were performed by PCR $5 \mu$ product added $1 \mu \mathrm{l}$ distillation water, $0.7 \mu \mathrm{l}$ buffer, and restriction enzime $0.3 \mu \mathrm{l}$, then incubated at $37^{\circ} \mathrm{C}$ for $16 \mathrm{~h}$. DNA cutting products were visualized on $2 \%$ agarose gel with $0.5 \times$ TBE buffer (Tris-Borate EDTA, then coloured ethidium bromide. Electrophoretic results were observed with the aid of UV light transilluminator.

\section{Analysis of genetic polymorphism}

Analysis of genetic polymorphism or SNPs (single nucleotide polymorphisms) from each locus of IGF1 $\mid$ SnaBI GH $\mid M S p$ I and OPN|BsrI were conducted by Poggene 32 packet programme for:

a. Genotype and allele frequency by computing genotype number of all genotypes in a population

b. Hardy-Weinberg (H-W) Equilibrium by testing ChiSquare calculation

c. Heterozygosity observation (Ho) and expectation (He) by estimating on the base on allele frequency

d. Shannon's Information index

\section{RESULTS AND DISCUSSION}

\section{Genotyping genes}

SNP polymorphisms in IGF1 gene to be considered as potential molecular markers for economic traits providing reproduction traits (Leonard et al. 2005; Lucy 2008; Sami et al. 2011; Singh et al. 2014). DNA amplification of IGF1, OPN, and GH genes using PCR techniques by following specific primer design was successfully performed on all blood samples of the crossed PO cattle observed. Amplification products were obtained for single birth as well as twins and multiple births of the crossed PO cattle from Sragen (S $=7 \mathrm{hd}$, and $\mathrm{M}=13 \mathrm{hd}$.) and also from Kendal ( $\mathrm{S}=9$ hd, and $\mathrm{M}=16 \mathrm{hd}$ ).

\section{IGF1 gene}

Bovine IGFI gene is located on chromosome 5 (BTA5) at nucleotide positions 66,532,877- 66,604,734 (UMD_3.1, Chromosome, Bos taurus, Ensembl) with the provisional nucleotide sequence is approximately 72 $\mathrm{kb}$ (ID number 281239) (Reyna et al. 2010). DNA amplification was performed at intron 1 of IGF1 gene that resulted in a DNA fragment size by 249 bp (Siadkowska et al. 2006). Amplicon products were genotyped by SnaBI restriction enzyme. However, SnaBI enzyme did not cut specific DNA cutting sites at the intron 1 of IGF1 of all the crossed PO cattle observed. This happened both for single birth as well as for twins and multiple births from the two locations. Genotyping IGF1|SnaBI locus in the crossed PO cattle produced only one fragment of $249 \mathrm{bp}$. This means that all these animals had only one type of genotype, namely $\mathrm{BB}$ genotype. In contrast, there was not found either AA genotype (223 and $26 \mathrm{bp}$ ) or AB genotype (249, 223 and $26 \mathrm{bp}$ ). None of the genetic variation or SNP of IGF1|SnaBI locus was possibly due to no $\mathrm{C} / \mathrm{T}$ base transition as a specific cutting site of SnaBI restriction enzyme.

\section{OPN gene}

Bovine OPN gene or SPPl gene comprises 7 exons spanning about $7 \mathrm{~kb}$ of genomic DNA (GenBank accession number NW 255516). OPN gene is composed of $6961 \mathrm{bp}$ in total length: $1331 \mathrm{bp}$ in processed length and 278 in protein product lengths. DNA amplicons of OPN gene were cut by a BsrI enzyme to detect a point mutation at specific base fragment at intron 4. Genetic polymorphism of OPN gene was studied by following Leonard et al. (2005) that found a C/T transition at intron 4 in a non-code 5 'region of OPN gene in Bos taurus cattle. Amplification products of DNA fragments of OPN|BsrI locus resulted in a base fragment size by $290 \mathrm{bp}$. For restricting DNA fragments of OPN|BsrI locus into two DNA bands by 200 and 90 bp was expressed as CC genotype. While, CT genotype was identified for the occurrence of three DNA bands by 290, 200, and $90 \mathrm{bp}$. If the DNA amplicons was not cut off by restriction enzyme resulting only one DNA band by $290 \mathrm{bp}$ for TT genotype resulted.

\section{GH gene}

PCR products of GH gene were cut by the Msp1 enzyme to detect a point mutation at intron 3 of $\mathrm{GH}$ gene. When DNA fragments at intron 3 of $\mathrm{GH}$ gene after the cutting by the Msp1 enzyme produced two bands by $223 \mathrm{bp}$ and $104 \mathrm{bp}$, so it was identified as BB genotype. For the producing only one DNA band by 327 bp was called AA genotype. When the existing three DNA bands of $327 \mathrm{bp}, 223 \mathrm{pb}$, and $104 \mathrm{bp}$ were named $\mathrm{AB}$ genotype. Results from this study were consistent to the previous study by Khatib et al. (2009) for identifying three $\mathrm{AA}, \mathrm{AB}$, and $\mathrm{BB}$ genotypes from the $\mathrm{GH} \mid \mathrm{Msp} 1$ gene in Bos taurus dairy cattle.

\section{Genotype and allele frequency}

Genetic diversity is expressed as the total number of genetic characters that build the genetic makeup of a species, breed or population. Genetic diversity serves as a way for populations to adapt to changing environments. While more genetic variations exist, it is 
Table 1. Genotype and allele frequencies of IGF1, OPN, and GH Genes of the crossed PO cattle based on birth type

\begin{tabular}{lcccccccccc}
\hline \hline Gene/ & \multicolumn{3}{c}{ Single Birth } & \multicolumn{3}{c}{ Twins / Multiple Births } \\
\hline Location & \multicolumn{3}{c}{ Genotype } & \multicolumn{2}{c}{ Allele } & \multicolumn{3}{c}{ Genotype } & \multicolumn{2}{c}{ Allele } \\
\hline IGF1 & AA & AB & BB & A & B & AA & AB & BB & A & B \\
Sragen & 0.000 & 0.000 & 1.000 & 0.000 & 1.000 & 0.000 & 0.000 & 1.000 & 0.000 & 1.000 \\
Kendal & 0.000 & 0.000 & 1.000 & 0.000 & 1.000 & 0.000 & 0.000 & 1.000 & 0.000 & 1.000 \\
Total & 0.000 & 0.000 & 1.000 & 0.000 & 1.000 & 0.000 & 0.000 & 1.000 & 0.000 & 1.000 \\
OPN & CC & CT & TT & C & T & CC & CT & TT & C & T \\
Sragen & 0.000 & 0.000 & 1.000 & 0.143 & 0.857 & 0.000 & 0.667 & 0.333 & 0.333 & 0.667 \\
Kendal & 0.000 & 0.250 & 0.750 & 0.214 & 0.786 & 0.000 & 0.471 & 0.529 & 0.300 & 0.700 \\
Total & 0.000 & 0.125 & 0.875 & 0.167 & 0.833 & 0.000 & 0.552 & 0.448 & 0.304 & 0.696 \\
GH & AA & AB & BB & A & B & AA & AB & BB & A & B \\
Sragen & 0.375 & 0.625 & 0.000 & 0.714 & 0.286 & 0.083 & 0.417 & 0.500 & 0.273 & 0.727 \\
Kendal & 0.000 & 0.000 & 1.000 & 0.000 & 1.000 & 0.118 & 0.471 & 0.412 & 0.344 & 0.656 \\
Total & 0.188 & 0.313 & 0.500 & 0.333 & 0.667 & 0.103 & 0.448 & 0.448 & 0.321 & 0.679
\end{tabular}

more likely that animals will have a better adaptation to the environment. Cattle is a diploid organism that has two potential alleles at a particular fragment of a gene. If a cattle have the same allele, it is expressed as homozygous, otherwise to be heterozygous. A codominant allele is very useful to serve as a genetic marker. The frequency of alleles and genotypes can reflect genetic diversity of animal population.

As previously stated that genotyping intron 1 of IGF1|SnaBI locus on all of the crossed PO cattle in this study produced the only $\mathrm{BB}$ genotype with the DNA fragment of $249 \mathrm{bp}$. This means each individual of both historical twin (multiple) births and the single birth of the crossed PO cattle from the two locations had the only BB genotype (Table 1 ). Thus only the B allele was found $(1,000)$, otherwise no A allele. An allele is said to be monomorphic if that allele frequency is more than 0.99 . No genetic variation or monomorphic of the specific base cutting site, known as $\mathrm{C} / \mathrm{T}$ base transition, at intron 1 of IGF1|SnaBI locus was identified. Certain SNPs or genotypes of IGF1 gene are presumed for having genetic control in stimulating multiple ovulation rates to give potential twins or multiple pregnancies (Echternkamp et al. 1990; Gregory et al. 1997; Singh et al. 2014). By the finding monomorphic base at the specific base of SnaBI cutting site from this results indicated that IGF1|SnaBI locus cannot be used to investigate possible genetic control of twins and multiple births in the crossbred PO cattle.

Several studies, however, identified an SNP at the intron 1 of IGF1 using a SnaBI restriction enzyme showing a $\mathrm{T}>\mathrm{C}$ transition at the specific cutting site of
SnaBI restriction enzyme in Cattle. Frequently B allele was reported dominant than $\mathrm{A}$ allele showing that $\mathrm{BB}$ cattle very dominant to those $\mathrm{AA}$ and $\mathrm{AB}$ cattle. Yurnalis et al. (2017) from a study in local Pesisir cattle in West Sumatera reported frequencies of AA, AB, and $\mathrm{BB}$ genotypes were successively $0.0125,0.0125$, and 0.9750 and resulted frequencies of $\mathrm{A}$ and $\mathrm{B}$ alleles were 0.00625 , and 0.99375 respectively. Genetic polymorphism of IGF-I gene was also reported from Bali cattle of which an SNP as a transition mutation T/C being identified by restriction enzyme $R s a \mathrm{I}$ at exon 4 with the frequency of $\mathrm{C}$ allele higher than that of $\mathrm{T}$ allele, namely 0.836 vs. 0.164 (Maskura et al. 2012). Furtherly genotyping IGF1 by PCR - RFLP method using TaqI and MspI restriction enzymes and amplification-created restriction site (ACRS) one by SnaBI, TasI and TaqI restriction enzymes in Poland Cattle, Szewczuk (2016) reported frequencies of the most common alleles by 0.67 for T allele (IGF1|SnaBI), 0.85 for A allele (IGF1|TasI), 0.95 for C allele (IGF1R $\mid$ TaqI), 0.84 for $\mathrm{G}$ allele (IGF1R $\mid$ MspI) and 0.69 for $\mathrm{G}$ allele (IGF1R $\mid$ TaqI).

Genotyping at intron 4 of OPN|BsrI polymorphism in the crossed PO cattle did not produce CC genotype for both single and twins or multiple births for the two locations. Single birth cattle in both locations had higher frequencies of TT genotype (0.750 to 1.000) than CT genotype $(0.000-0.250)$. Whilst for twins and multiple births ones had higher frequencies of CT genotype $(0.471-0.667)$ than TT one $(0.333-0.529)$. These results suggested that single birth had more common for homozygous BB cattle, whereas twins and 
multiple births were more frequent in heterozygous CT cattle. High CT and TT genotypes resulted in higher T allele against $\mathrm{C}$ allele for both single birth or twins and multiple births of the crossed PO cattle in this study. Pareek et al. (2008) reported OPN or SPP1 $C>T$ SNP polymorphism was also found within the intron IV of bovines SPPI gene that was investigated in selected breeds of beef (Hereford and Limousine) and dairy (Polish HF and Polish Red) cattle. The study revealed significant differences in the distribution of $C$ and $T$ alleles among the analysed panel of cattle breeds. In general allele frequencies of $\mathrm{T}$ and $\mathrm{C}$ were 0.59 and 0.41 respectively; so frequencies of TT, CT and CC genotypes were $34.69,48.62$, and 16.69 respectively.

Growth hormone $(\mathrm{GH})$ is an anabolic hormone synthesized and secreted by somatotropic cells in an anterior pituitary lobe (Ayuk \& Sheppard 2006). The specific DNA cutting site at intron 3 of GH|MspI locus lies at position 1547 (Zhang et al. 1993). Genotyping DNA fragments at intron 3 of GH|MspI SNP polymorphism in the crossed $\mathrm{PO}$ cattle in twin and multiple births had higher frequencies of $\mathrm{AB}$ genotype $(0.417$ - 0.471) and BB genotype $(0.412-0.500)$ than AA genotype $(0.083-0.118)$. The same pattern was found in single birth type. AB cattle were found higher than AA one. Even in Kendal, single birth cattle was just identified only for BB genotype. These results indicated that both single birth and twins (multiple) births of the crossed $\mathrm{PO}$ cattle had higher $\mathrm{AB}$ and $\mathrm{BB}$ genotype than $\mathrm{AA}$ one. Thus frequencies of $\mathrm{B}$ allele were higher than those of A allele A across birth type and location. DNA polymorphism of $\mathrm{GH} \mid \mathrm{MspI}$ locus in Aceh cattle was reported by Putra et al. (2013) to have only TT genotype (BB genotype) resulting frequency of $\mathrm{T}$ allele was 1,000 and monomorphic.

\section{Heterozygosity}

Estimation of heterozygosity value was obtained to determine the level of genetic diversity in the crossed PO cattle population observed. This information can be used to help the effectiveness of selection program on breeding stocks to be used as a genetic source in the next generation (Marson et al. 2005). Heterozygosity observation (Ho) of OPN|BsrI and GH|MspI loci of the crossed PO cattle by birth type are listed in Table 2. Heterozygosity expectation $(\mathrm{He})$ is required to know the difference to heterozygosity observation (Ho). For the IGF1|SnaBI locus with the only BB genotype in all of the crossed PO cattle lead to Ho value of 0.000 .

For OPN|BsrI locus in the crossed PO cattle from both locations showed Ho values were higher than $\mathrm{He}$ values. It was for single birth namely $\mathrm{Ho}=0.2857$ 0.4286 vs $\mathrm{He}=0.2637-0.3626$; while that for multiple births, namely $\mathrm{Ho}=0.6000-0.6667$ vs $\mathrm{He}=0.4345-$ 0.4638 . Ho values were higher than the He values from this OPN|BsrI locus could be an indication for a good heterozygosity level this gene polymorphism in the crossed PO cattle either for single birth and twins or multiple births. OPN|BsrI locus, therefore, could be considered as a molecular selection in regarding increase probability of twins or multiple births in beef cattle. According to Javanmard et al. (2005), a heterozygosity value above $0.5(50 \%)$ indicates a high variation of a gene in a population. Molecular selection by using OPN|BsrI gene might be possible to give a good selection respond in improving twin or multiple births in beef cattle.

However, the opposite result was found to GH|MspI locus in which the crossed PO cattle in multiple births had relatively smaller Ho values compared to $\mathrm{He}$ values, ie $\mathrm{Ho}=0.3636-0.4375$ vs $\mathrm{He}=0.4156-$ 0.4657 . This indicated heterozygosity level of GH|MspI

Table 2. Heterozygosity observation (Ho) and heterozygosity expectation (He) of OPN and GH genes of the crossed Peranakan Ongole based on birth type

\begin{tabular}{cccccccc}
\hline \hline \multirow{2}{*}{ Gene } & Location & \multicolumn{3}{c}{ Single birth } & \multicolumn{3}{c}{ Twins / Multiple Births } \\
\cline { 2 - 8 } OPN & Heterozygosity & Ho & He & Polymor. & Ho & He & Polymor \\
\cline { 2 - 8 } & Sragen & 0.2857 & 0.2637 & $100 \%$ & 0.6667 & 0.4638 & $100 \%$ \\
& Kendal & 0.4286 & 0.3626 & $100 \%$ & 0.6000 & 0.4345 & $100 \%$ \\
GH & Total & 0.3333 & 0.2874 & $100 \%$ & 0.6071 & 0.4305 & $100 \%$ \\
& Sragen & 0.5714 & 0.4396 & $100 \%$ & 0.3636 & 0.4156 & $100 \%$ \\
& Kendal & 0.0000 & 0.0000 & $0 \%$ & 0.4375 & 0.4657 & $100 \%$ \\
& Total & 0.2667 & 0.4598 & $100 \%$ & 0.4286 & 0.4442 & $100 \%$ \\
\hline
\end{tabular}


Anggareni et al. Genetic polymerphisms of IGF1, GH, and OPN genes in crosses Peranakan Ongole cattle based on birth type in Central Java

Tabel 3. Hardy-Weinberg Equilibrium of OPN and GH genes of the crossed Ongole Grade cattle based on birth type

\begin{tabular}{|c|c|c|c|c|c|c|c|}
\hline \multirow{2}{*}{ Gene } & \multirow{2}{*}{$\frac{\text { Location }}{\text { H-W Equi. }}$} & \multicolumn{3}{|c|}{ Single Birth } & \multicolumn{3}{|c|}{ Twins/Multiple Births } \\
\hline & & $\chi^{2}$ & $\chi^{2}(0,05)$ & Signif. & $\chi^{2}$ & $\chi^{2}(0,05)$ & Signif. \\
\hline \multirow[t]{3}{*}{ OPN } & Sragen & 0.9009 & 0.7630 & $*$ & 2.5667 & 0.1091 & $*$ \\
\hline & Kendal & 0.2143 & 0.7857 & $\mathrm{~ns}$ & 2.4000 & 0.1213 & $*$ \\
\hline & Total & 0.1667 & 0.8333 & $\mathrm{~ns}$ & 4.9555 & 0.0260 & $*$ \\
\hline \multirow[t]{3}{*}{ GH } & Sragen & 0.8000 & 0.3711 & $*$ & 0.2000 & 0.6547 & ns \\
\hline & Kendal & - & - & - & 0.0636 & 0.8008 & ns \\
\hline & Total & 2.8884 & 0.08922 & $*$ & 0.0362 & 0.8492 & ns \\
\hline
\end{tabular}

*) values in the same row shows significantly difference $(\mathrm{P}<0.05)$

locus was relatively low in twin and multiple births in both locations. Generally, OPN|BsrI and GH|MspI loci.had high polymorphic level $(100 \%)$, the exception was for $\mathrm{GH} \mid \mathrm{MspI}$ for the single birth type from Kendal which was monomorphic with only the BB genotype

\section{Hardy-weinberg equilibrium}

Chi-square analysis can be used to determine whether or not the genotype frequency $\left(\mathrm{p}^{2}, 2 \mathrm{pq}, \mathrm{q}^{2}\right)$ or allele frequencies ( $p$ and $q$ ) in a population. The results of Chi-square analysis can be used as an indicator of population equilibrium known as Hardy - Weinberg Equilibrium. Chi-square value $\left(\chi^{2}\right)$ of OPN|BsrI locus in the crossed PO cattle showed significantly different $\left(\chi^{2}>\chi^{2}(0.05)\right)$ for single and multiple births in both locations, excepting for single birth in Kendal. It can be stated that allele frequency of OPN|BsrI locus of the crossed PO cattle was not in equilibrium for twins and multiple births from both locations.

$\chi^{2}$ value of the crossed PO cattle of GH|MspI locus from single birth type could not calculate because of it was monomorphic. Genotype frequencies in the crossed PO cattle, therefore, did not meet the assumptions for Hardy-Weinberg equilibrium analysis. Furthermore, $\mathrm{GH} \mid \mathrm{MspI}$ polymorphism in multiple births in both locations had Chi-Square values higher $((\chi 2>\chi 2(0.05))$, so it can be stated that these two populations were in Hardy - Weinberg equilibrium. This means that mating among individual cattle from twins and multiple births in both locations was in equilibrium. A population can be stated in a Hardy-Weinberg equilibrium if the frequency of dominant and recessive alleles are constant from generation to generation, there is no selection, mutation, migration, and genetic drift.

\section{CONCLUSION}

Genotyping intron 1 of IGF1|SnaBI locus on all of the crossed PO cattle in this study produced the only
BB genotype with the DNA fragment of $249 \mathrm{bp}$. By the finding monomorphic base at the specific base of SnaBI cutting site from this results indicated that IGF1|SnaBI locus cannot be used to investigate possible genetic control of twins and multiple births in the crossbred PO cattle. Whilst genotyping $\mathrm{GH} \mid M S p \mathrm{I}$ and $\mathrm{OPN} \mid B s r \mathrm{I}$ loci were polymorphic that useful as initial information for molecular selection on fertility traits in beef cattle. $\mathrm{GH} \mid \mathrm{MspI}$ locus in the crossed PO cattle from multiple births was in equilibrium $\mathrm{H}-\mathrm{W}$ equilibrium contrasting to OPN|BsrI locus indicating that the frequencies of AA and BB alleles of GH|MspI were constant by generations.

\section{REFERENCES}

Ayuk J, Sheppard MC. 2006. Growth hormone and its disorders. Postgrad Med J. 82:24-30.

Çobanoğlu Ö. 2010. Twinning in cattle: Desirable or undesirable?. J Biol Environment Sci. 4:1-8.

Deb RU, Singh, Kumar S. 2012. Molecular tools and their application in genetic research. Meerut, UP, (India): Technical Bulletin, Project Directorate on Cattle, ICAR.

[DGLAH] Directorate General of Livestock and Animal Health. 2017. Livestock statistic book. Jakarta (Indones): Ministry of Agriculture.

Echternkamp SE, Gregory KE, Dickerson GE, Cundiff LV, Koch RM, Van Vleck LD. 1990. Twinning in cattle: II. Genetic and environmental effects on ovulation rate in pubertal heifers and postpartum cows and the effects of ovulation rate on embryonic survival. J Anim Sci. 68:1877.

Gregory KE, Echternkamp SE, Cundiff LV. 1997. Effects of twinning on dystocia, calf survival, calf growth, carcass traits, and cow productivity. J Anim Sci. 74:1223-1233.

Hull KL, Harvey S, 2001. Growth hormone: roles in female reproduction. Rev J Endocrinol. 168:1-23.

Javanmard A, Asadazadeh N, Banabazi MH, Tavakolian J. 2005. The allele and genotype frequencies of bovine 
pituitary-specific transcription factor and leptin genes in Iranian cattle and buffalo populations using PCR-RFLP. Iranian J Biotechnol. 3:104-108.

Johnson GA, Burghardt RC, Joyce MM, Spencer TE, Bazer FW, Gray CA, Pfarrer C. 2003. Osteopontin is synthesized by uterine glands and a $45-\mathrm{kDa}$ cleavage fragment is localized at the uterine-placental interface throughout ovine pregnancy. Biol Reprod. 69:92-98.

Karlsen A, Ruane J, Klemetsdal G, Heringstad B. 2000. Twinning rate in Norwegian cattle: Frequency, (co)variance components, and genetic trends. J Anim Sci. 78:12-20.

Khatib H, Huang W, Wang X, Tran AH, Bindrim AB, Schutzkus V, Monson RL, Yandell BS. 2009. Single gene and gene interaction effects on fertilization and embryonic survival rates in cattle. J Dairy Sci. 92:22382247.

Komisarek J, Dorynek Z. 2002. Genetic aspects of twinning cattle. J Appl Genet. 43:55-68.

Leonard S, Khatib H, Schutzkus V, Chang YM, Maltecca C. 2005. Effects of the osteopontin gene variants on milk production traits in dairy cattle. J Dairy Sci. 88:40834086.

Li MC, Fang Q, He ZM, Gao Y, Zhou Y. 2013. Placental expression of osteopontin (OPN) in monochorionic twins with discordant growth. Placenta. 34:288-290.

Lien S, Karlsen A, Klemetsdal G, Vcge DL, Olsaker I, Klungland H, Aasland M, Heringstad B, Ruane J, Gomez-Raya L. 2000. A primary screen of the bovine genome for quantitative trait loci affecting the twinning rate. Mamm Genome. 11:877-882.

Lucy MC. 2001. Reproductive loss in high-producing dairy cattle: Where will it end? J Dairy Sci. 84:1277-1293.

Lucy MC. 2008. Functional differences in the growth hormone and insulin-like growth factor axis in cattle and pigs: implications for post-partum nutrition and reproduction. Reprod Domest. Anim. 43(Suppl. 2), 3139.

Maskura C, Armana C, Sumantrib E, Gurnadi, Muladno. 2012. A Novel single nucleotide polymorphism in exon 4 of insulin-like growth factor-1 associated with production traits in Bali cattle. Media Peternakan. 35:96-101

Marson EP, Ferraz JBS, Meirelles FV, Balieiro JCC, Eler JP, Figuerido LGG, Mourao GB. 2005. Genetik characterization of European-Zebu composite bovine using RFLP markers. J Genet Mol Res. 4:496-505.

Pareek CS, Zięba M, Michno J, Czarnik U, Zwierzchowski L. 2008. Study of SNP C>T polymorphism within the candidate genes for dairy and beef traits in a panel of selected cattle breeds. J. Agro-Biology. 25:121-124.
Putra WPB, Hartatik T, Sumadi. 2013. Growth hormone gene genotyping by Msp I restriction enzyme and PCR-RFLP methods in Aceh cattle breed at Indrapuri district of Aceh province. J Indones Trop Anim Agric. 38:207211.

Reyna XF, De la Rosa, Montoya HM, Castrellón VV, Rincón AMS, Bracamonte MP, Vera WA. 2010. Polymorphisms in the IGF-1 gene and their effect on growth traits in Mexican beef cattle. Genet Mol Res. 9:875-883.

Sami AJ, Nazir MT, Jabeen Z, Shakoori AR. 2011. Gene study within the 5' flanking regions of growth hormone gene of the first exon in Bos indicus. Afr J Biotechnol. $10: 332-336$

Sawa A, Bogucki M, Kr e e zel-Czopek S. 2012. Reproduction performance of cows with single, twin and triplet calves. Acta Vet Brno. 81:347-352.

Siadkowska E, Zwierzchowski L, Oprządek J, Strzałkowska N, Bagnicka E, Krzyżewski J. 2006. Effect of polymorphism in $I G F-1$ gene on production traits in Polish Holstein-Friesian cattle. Anim Sci Papers Reports. 24:225-237.

Singh U, Deb R, Alyethodi RR, Alex R, Kumar S, Chakraborty S, Dhama K, Sharma A. 2014. Molecular markers and their applications in cattle genetic research: A review. Biomark Genom Medic. 6:49-58.

Szewczuk M. 2016. Association of single nucleotide polymorphisms in genes coding insulin-like growth factor 1 system and milk production traits in Montbeliarde cows. South Afr J Anim Sci. 46:191-195.

Yang WC, Li SJ, Tang KQ. 2010. Polymorphisms in the 50 upstream regions of the FSH receptor gene, and their association with superovulation traits in Chinese Holstein cows. Anim Reprod Sci. 119:172-177.

Yurnalis, Arnim, Putra DE. 2017. Polymorphism of insulinlike growth factor 1 gene (IGF1/TasI, IGF1/SnaBI, $I G F 1 / R s a \mathrm{I})$ and the association with daily gain of Pesisir cattle local breed from West Sumatera, Indonesia. Pak J Biol Sci. 20:2010-2016.

Zhang HM, Maddock KC, Brown DR, Denise SK, Ax RL. 1993. A novel allele of the bovine somatotropin gene detected by PCR-RFLP analysis. J Anim Sci. 71:2276.

Zhao Y, Xu H, Zhao Z, Narisu, Mao J, Guan D, Xie C. 2015. Polymorphisms of osteopontin gene and their association with placental efficiency and prolificacy in goats. J Appl Anim Res. 43:272-278.

Zhou GL, Jin HG, Guo SL, Zhu Q, Whu YH. 2005. Association of genetic polymorphism in GH gene with milk production traits in Beijing Holstein cows. J Biosci. 30:595-598. 